\title{
First synthesis and oxidative properties of polymer-supported IBX
}

\author{
Marcel Mülbaier and Athanassios Giannis* \\ Universität Leipzig, Institut für Organische Chemie, Johannisallee 29, D-04103 Leipzig \\ E-mail: giannis@chemie.uni-leipzig.de \\ Dedicated to Professor A. Varvoglis \\ (received 07 Mar 03; accepted 15 May 03; published on the web 15 Sep 03)
}

\begin{abstract}
A polymer-supported analogue of the IBX-reagent (1-hydroxy-1,2-benziodoxol-3(1H)-one 1oxide) has been synthesized. Synthesis and oxidative properties of this new and efficient reagent are described. With this reagent is it now possible to oxidize alcohols selectively to the corresponding ketones and aldehydes. Over oxidation to carboxylic acids has not been observed. This new reagent combines the advantages of polymer-supported reagents with those of the IBX reagent.
\end{abstract}

Keywords: IBX, polymer-supported reagents, oxidation, alcohols

\section{Introduction}

In the last 20 years hypervalent iodine reagents enjoyed an increasing popularity in organic synthesis. ${ }^{1-6}$ They can be used for a wide range of chemical transformations, especially as reagents for oxidations. $^{7-11}$ For these purposes, iodinanes like (diacetoxyiodo)-benzene, [bis(trifluoroacetoxy)iodo]-benzene, the Dess-Martin periodinane (DMP) and 1-hydroxy-1,2benziodoxol-3(1H)-one 1-oxide (IBX) 1 are particularly suitable. The advantages of these reagents are high efficiency, easy availability, mild reaction conditions and (with the exception

of DMP) stability against moisture and oxygen. Furthermore they are environmentally safe and can be regenerated.

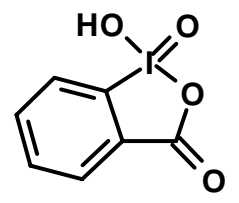

Figure 1. IBX. 
The combination of these properties with the advantages of polymer supported reagents ${ }^{12-15}$ is an attractive and worthwhile aim. Recently, we reported on synthesis and oxidative properties of two aminomethylpolystyrene bound (diacetoxyiodo)-benzene derivatives. ${ }^{16}$ In the context of these investigations we envisaged the development of a polymer supported IBX reagent. Here we present the synthesis of such an IBX derivative and show that it is a powerful oxidant with broad applicability.

\section{Results and Discussion}

\section{Synthesis of the IBX-reagent}

The synthesis of reagent 7 was accomplished starting from commercially available 2-amino-5hydroxybenzoic acid 2 (Figure 2).
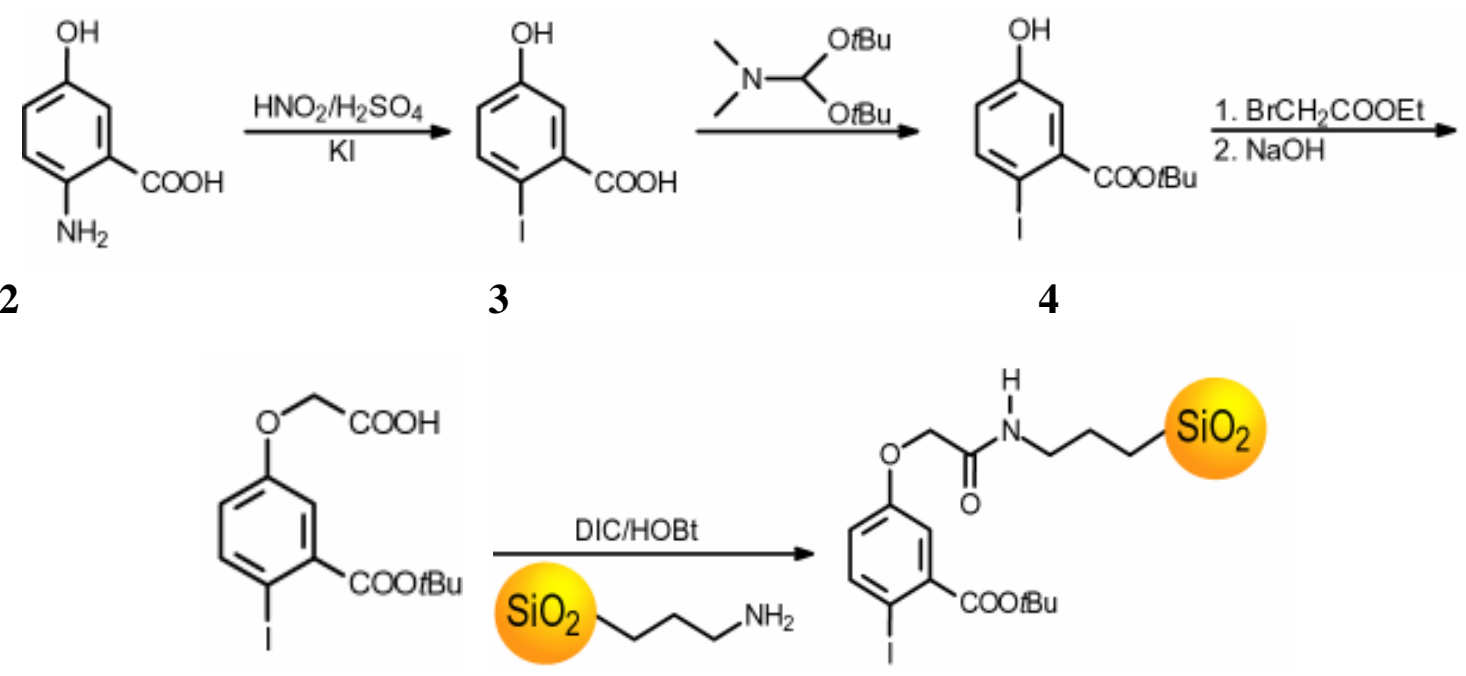

5

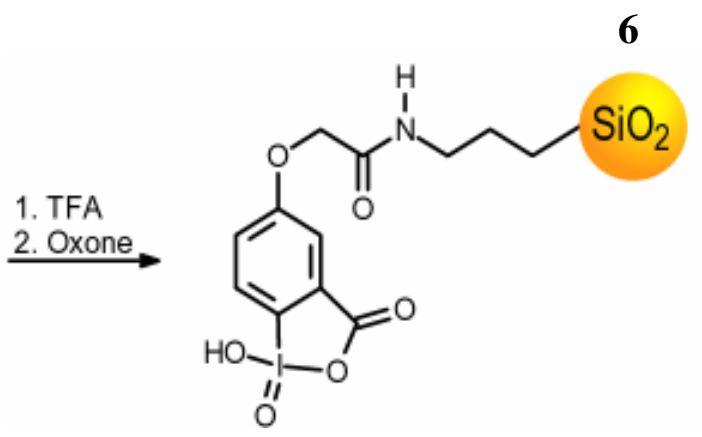

$\mathrm{DIC}=$ Diisopropylcarbodiimide

7

$\mathrm{HOBt}=1$-Hydroxybenzotriazole

TFA $=$ Trifluoroacetic acid

Figure 2. Synthesis of polymer-supported IBX. 
Treatment of compound 2 with $\mathrm{NaNO}_{2} / \mathrm{H}_{2} \mathrm{SO}_{4}$ and excess $\mathrm{KI}$ afforded derivative 3, which was transformed to the tert-butylester 4 using $N, N$-dimethylformamide-di-tert-butyl acetal. ${ }^{17}$ After alkylation of the phenolic hydroxy group with ethyl $\alpha$-bromoacetate and subsequent hydrolysis with $\mathrm{NaOH}$, compound $\mathbf{5}$ was obtained. This linker was subsequently coupled to aminopropylsilica gel with $\mathrm{DIC} / \mathrm{HOBt}$ to give compound $\mathbf{6}$. Cleavage of the tert-butylester with trifluoroacetic acid and oxidation with oxone ${ }^{18}$ afforded the final reagent $7 .{ }^{19}$

\section{Application of the reagent}

Now various primary and secondary alcohols can be oxidised with reagent 7 (Table 1).

Table 1. Oxidations of Alcohols with Reagent 7

Entry


Table 1. Continued

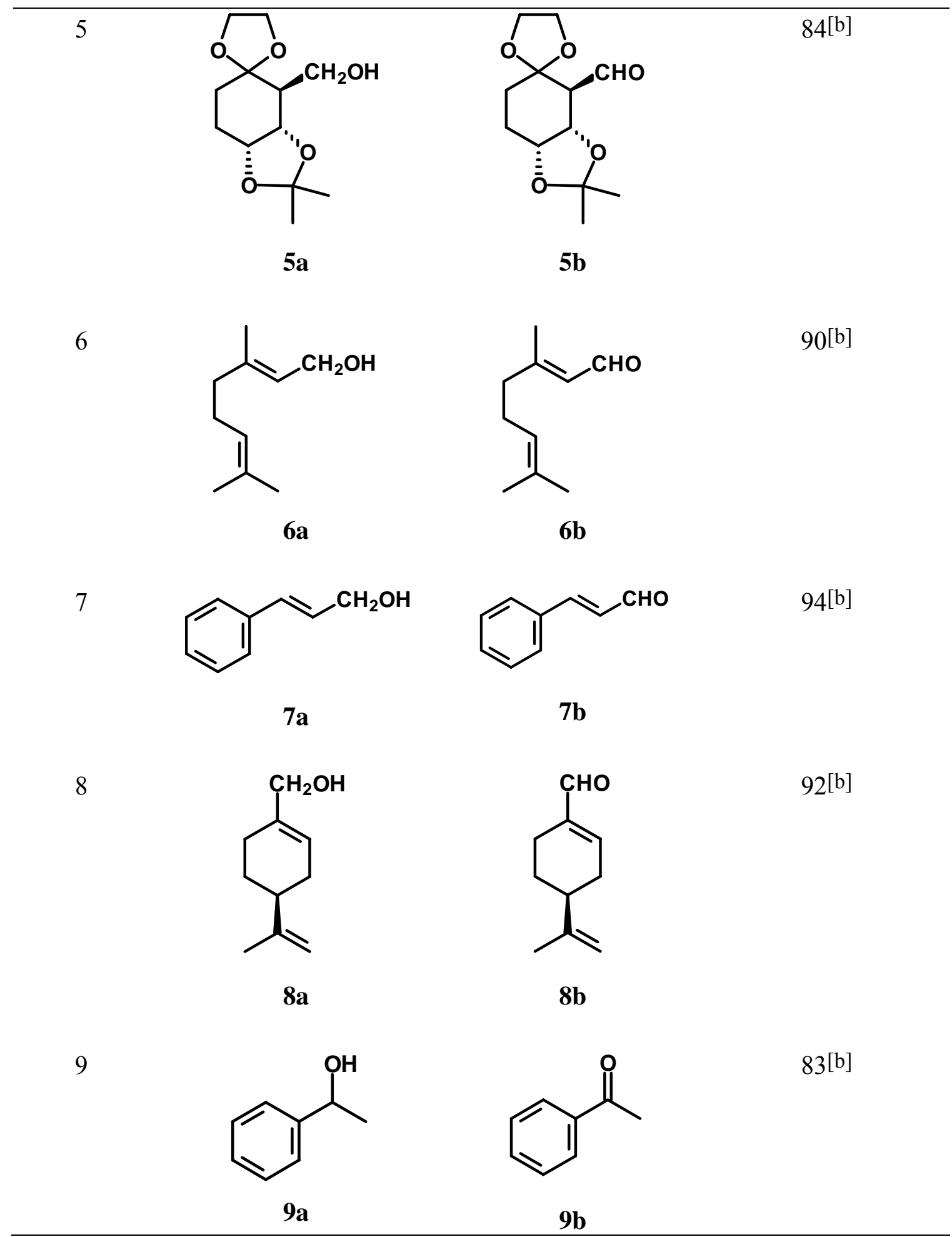


Table 1. Continued

10<smiles>C=CC(O)C(C)(C)CC(C)(C)C</smiles>

10a

11

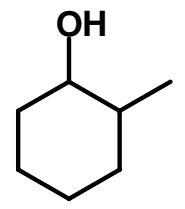

11a<smiles>C=CC(=O)C(C)(C)CC(C)(C)C</smiles>

10b

80

82

${ }^{\text {a }}$ Purity estimated by GC/MS.

${ }^{\mathrm{b}}$ Yield after flash chromatography.

Whereas in the case of soluble IBX, DMSO as solvent is indispensable at room temperature, reagent 7 also works in THF. In comparison to DMSO, reactions proceed faster in that solvent. Even the presence of water (1-10\%) has no negative influence on yield and reaction time. The products are obtained with high purity and the general yields are high to excellent. During oxidation of primary alcohols to the corresponding aldehydes no over oxidation to the carboxylic acid was detected.

It is particularly interesting that oxidation of $\mathbf{4 a}$ leads to $\mathbf{4 b}$ with only the primary hydroxy group oxidised, even if reagent $\mathbf{7}$ is added in threefold excess. ${ }^{20}$ In order to get some clues of that remarkable selectivity we tried to oxidise menthol and 3-methyl-2-butanol with reagent $\mathbf{6}$. The yields of the corresponding ketones were poor $(<5 \%)$ and could not be increased even after longer reaction times (48h). On the other hand, 2-methylcyclohexanol 11a (racemic mixture) is oxidised easily and in high yield to 2-methylcyclohexanone 11b. The exact reason of this diverse reactivity is yet not fully understood and is subject of current investigations.

\section{Conclusions}

In summary, we have discovered a powerful and versatile oxidation system ${ }^{21}$ which is particularly suitable for oxidation of alcohols under mild conditions to the corresponding aldehydes and ketones. This method combines the advantages of polymer-supported reagents with the advantages of IBX which is superior to the Dess-Martin reagent in stability, efficiency and versatility. ${ }^{7}$ The reduced form of reagent 7 is easily separated by simple filtration and can be regenerated by oxidation with oxone. ${ }^{19}$ The products are obtained in high purity. Side reactions were not detected. Finally our system could be suitable for the polymer-supported synthesis of 
amino sugars ${ }^{20}$ and the cyclization of anilides. ${ }^{21,22}$ Currently we are focusing our investigations on these aspects.

\section{Experimental Section}

General Procedures. ${ }^{1} \mathrm{H}$ NMR (and ${ }^{13} \mathrm{C}$ NMR) spectra were recorded on a Bruker AC-250 (DRX-500) spectrometer with the solvent residual peak as internal standard. The GC/MS spectra were recorded on a HP 5890 Series II Gas Chromatograph coupled with HP 5972 Series Mass Selective Detector (specifications of the column: Macherey Nagel Optima 1/20 $\mu \mathrm{m}, 25 \mathrm{~m}$ x 0.2 mm ID). Mass spectra were recorded on a Finnegan Mat MS90 mass spectrometer. Elemental analysis was performed on a Heraeus CHN-O-RAPID. Iodometric analysis (titration with thiosulfate solution after pulping, starch solution as indicator) was performed in the Institut für Anorganische Chemie, Universität Karlsruhe, Germany. Merck silica gel 60 for column chromatography and Merck precoated TLC plates, silica gel $\mathrm{F}_{254}$ for TLC were used. All starting materials and chemicals are commercially available and were used without further purification. All solvents were purified and, when necessary, dried in the usual way. Melting points were measured with a Büchi 530 and are not corrected.

2-Iodo-5-hydroxybenzoic acid (3). To a stirred suspension of commercially available 2-amino5-hydroxybenzoic acid $(5.66 \mathrm{~g}, 37 \mathrm{mmol})$ in $100 \mathrm{ml}$ of water is added slowly $6.7 \mathrm{ml}$ of concentrated sulfuric acid. Thereafter a solution of $\mathrm{NaNO}_{2}(3.8 \mathrm{~g}, 55.4 \mathrm{mmol}$, in $20 \mathrm{ml}$ of water) is added dropwise, in doing so the suspension is cooled $<5^{\circ} \mathrm{C}$ with an ice/salt bath. After this addition a solution of $\mathrm{KI}(9.2 \mathrm{~g}, 55.4 \mathrm{mmol}$, in $20 \mathrm{ml}$ of water) is added dropwise and the solution is heated to $95-100^{\circ} \mathrm{C}$ for one hour. Afterwards the solution is stirred at room temperature for about $12 \mathrm{~h}$. The crude product is crystallized at $4{ }^{\circ} \mathrm{C}$ from the reaction mixture and filtered off. For further purification it is necessary to recrystallize the product in boiling water to give 3 in $95 \%$ yield $(9.21 \mathrm{~g}, 35 \mathrm{mmol})$.

Analytical data: melting point $188^{\circ} \mathrm{C}, \mathrm{R}_{\mathrm{f}} 0.3$ (hexane/ethyl acetate/acetic acid 1:1:0.02), ${ }^{1} \mathrm{H}-$ NMR (500MHz, DMSO-d 6$): \delta(\mathrm{ppm})=9.98(\mathrm{~s}, 1 \mathrm{H}, \mathrm{COOH}) ; 7.70(\mathrm{~d}, \mathrm{~J}=8.5 \mathrm{~Hz}, 1 \mathrm{H}, \mathrm{C}(3)-\mathrm{H})$; $7.12(\mathrm{~d}, \mathrm{~J}=3.0 \mathrm{~Hz}, 1 \mathrm{H}, \mathrm{C}(6)-\mathrm{H}) ; 6.68\left(\mathrm{dd}, \mathrm{J}=8.6 \mathrm{~Hz}, \mathrm{~J}^{\prime}=3.0 \mathrm{~Hz}, 1 \mathrm{H}, \mathrm{C}(4)-\mathrm{H}\right),{ }^{13} \mathrm{C}-\mathrm{NMR}$ $\left(125.8 \mathrm{MHz}, \mathrm{DMSO}-\mathrm{d}_{6}\right): \delta(\mathrm{ppm})=167.9(\mathrm{COOH}) ; 157.4(\mathrm{C}(5)) ; 141.3(\mathrm{C}(3)) ; 137.5(\mathrm{C}(1))$; 120.2 (C(4)); $117.4(\mathrm{C}(6)) ; 80.0(\mathrm{C}(2))$, EI-MS $\left(90^{\circ} \mathrm{C}\right)$ calc. $\mathrm{m} / \mathrm{z} 263.9$, found $\mathrm{m} / \mathrm{z} 263.9$.

2-Iodo-5-hydroxybenzoic acid-tert-butyl ester (4). Under inert conditions 2-Iodo-5hydroxybenzoic acid (3) $(2.65 \mathrm{~g}, 10.05 \mathrm{mmol})$ is dissolved in $15 \mathrm{ml}$ of toluol. The solution is stirred, heated to $80^{\circ} \mathrm{C}$ and $N, N$-dimethyl formamide-di(tert-butylacetal) $(10 \mathrm{ml}, 42 \mathrm{mmol})$ is added dropwise in about 20 minutes. Thereafter the solution is stirred again for about 30 minutes at the same temperature. The reaction mixture is now cooled to room temperature and washed with $15 \mathrm{ml}$ of water, $20 \mathrm{ml}$ of saturated $\mathrm{NaHCO}_{3}$ solution and $10 \mathrm{ml}$ brine. The organic layer is dried with $\mathrm{Na}_{2} \mathrm{SO}_{4}$ and the solvent is evaporated in vacuo. The crude product is further cleaned 
by flash column chromatography (eluent: hexane/ethyl acetate 2:1) to give analytical pure 4 $(1.09 \mathrm{~g}, 3.41 \mathrm{mmol})$ in 34\% yield as a yellow oil.

Analytical data: $\mathrm{R}_{\mathrm{f}} 0.3$ (hexane/ethyl acetate $3: 1,{ }^{1} \mathrm{H}-\mathrm{NMR}\left(500 \mathrm{MHz}, \mathrm{CDCl}_{3}\right): \delta(\mathrm{ppm})=7.65(\mathrm{~d}$, $\mathrm{J}=8.6 \mathrm{~Hz}, 1 \mathrm{H}, \mathrm{C}(3)-\mathrm{H}) ; 7.20(\mathrm{~d}, \mathrm{~J}=3.0 \mathrm{~Hz}, 1 \mathrm{H}, \mathrm{C}(6)-\mathrm{H}) ; 6.66\left(\mathrm{dd}, \mathrm{J}=8.6 \mathrm{~Hz}, \mathrm{~J}^{\prime}=3.1 \mathrm{~Hz}, 1 \mathrm{H}\right.$, $\mathrm{C}(4)-\mathrm{H}) ; 1.58(\mathrm{~s}, 9 \mathrm{H}, t \mathrm{Bu}),{ }^{13} \mathrm{C}-\mathrm{NMR}\left(125.8 \mathrm{MHz}, \mathrm{CDCl}_{3}\right): \delta(\mathrm{ppm})=167.3\left(\mathrm{COO}^{t} \mathrm{Bu}\right) ; 156.1$ $(\mathrm{C}(5)) ; 141.5(\mathrm{C}(3)) ; 137.9(\mathrm{C}(1)) ; 120.2$ (C(4)); 117.8 (C(6)); 83.7 (quart $\mathrm{C}) ; 80.8(\mathrm{C}(2)) ; 28.0$ $\left(\mathrm{CH}_{3}\right)$, EI-MS $\left(50^{\circ} \mathrm{C}\right)$ calc. $\mathrm{m} / \mathrm{z} 320.0$, found $\mathrm{m} / \mathrm{z} 320.0$.

5-Carboxymethoxy-2-iodobenzoic acid-tert-butyl ester (5). 2-Iodo-5-hydroxybenzoic acidtert-butyl ester (4) (619 mg, $1.93 \mathrm{mmol})$ is dissolved in $15 \mathrm{ml}$ of DMF. The reaction mixture is cooled to $0^{\circ} \mathrm{C}$, then $\mathrm{NaH}(194 \mathrm{mg}, 50-60 \%$-suspension in oil, $4.84 \mathrm{mmol}$ ) is added. This mixture is stirred for about 10 minutes until no further hydrogen is formed. Thereafter $\alpha$-bromoethyl acetate $(0.26 \mathrm{ml}, 2.32 \mathrm{mmol})$ is added dropwise. After addition the reaction mixture is stirred again for 1.5 hours at $0^{\circ} \mathrm{C}$. When the reaction is complete, $20 \mathrm{ml}$ of water are added. Then the mixture is extracted with diethyl ether. The combined organic layers are dried with $\mathrm{Na}_{2} \mathrm{SO}_{4}$ and the solvent is removed in vacuo. The crude diester is cleaned up by flash column chromatography (hexane/ethyl acetate $3: 1)$ to give an yellow oil (610 $\mathrm{mg}, 1.5 \mathrm{mmol}, 78 \%$ yield). Analytical data of the diester: $\mathrm{R}_{\mathrm{f}} 0.5$ (hexane/ethyl acetate $\left.3: 1\right),{ }^{1} \mathrm{H}-\mathrm{NMR}\left(500 \mathrm{MHz}, \mathrm{CDCl}_{3}\right)$ : $\delta(\mathrm{ppm})=7.72(\mathrm{~d}, \mathrm{~J}=8.7 \mathrm{~Hz}, 1 \mathrm{H}, \mathrm{C}(3)-\mathrm{H}) ; 7.20(\mathrm{~d}, \mathrm{~J}=2.9 \mathrm{~Hz}, 1 \mathrm{H}, \mathrm{C}(6)-\mathrm{H}) ; 6.65(\mathrm{dd}, \mathrm{J}=8.7 \mathrm{~Hz}$, $\left.\mathrm{J}^{\prime}=2.9 \mathrm{~Hz}, 1 \mathrm{H}, \mathrm{C}(4)-\mathrm{H}\right) ; 4.55$ (s, 2H, $\mathrm{CH}_{2}$ methoxy); 4.19 (q, J = 7.1Hz, 2H, $\mathrm{CH}_{2}$ ethoxy); 1.54 $(\mathrm{s}, 9 \mathrm{H}, \mathrm{tBu}) ; 1.22\left(\mathrm{t}, \mathrm{J}=4.2 \mathrm{~Hz}, 3 \mathrm{H}, \mathrm{CH}_{3}\right.$ ethoxy), ${ }^{13} \mathrm{C}-\mathrm{NMR}\left(125.8 \mathrm{MHz}, \mathrm{CDCl}_{3}\right): \delta(\mathrm{ppm})=$ $168.0\left(\mathrm{COO}^{t} \mathrm{Bu}\right) ; 165.4$ (COOEt); 157.5 (C(5)); 141.5 (C(3)); 138.0 (C(1)); 118.7 (C(4)); 117.0 $(\mathrm{C}(6)) ; 83.1$ (quart $\mathrm{C}) ; 82.6(\mathrm{C}(2)) ; 65.2\left(\mathrm{CH}_{2}\right.$ methoxy); $61.4\left(\mathrm{CH}_{2}\right.$ ethoxy); $27.9\left({ }^{t} \mathrm{Bu}\right) ; 14.0$ $\left(\mathrm{CH}_{3}\right.$ ethoxy), EI-MS $\left(70^{\circ} \mathrm{C}\right)$ calc. $\mathrm{m} / \mathrm{z} 406.1$, found $\mathrm{m} / \mathrm{z} 406.1$

The diester $(1.56 \mathrm{~g}, 3.84 \mathrm{mmol})$ is now dissolved in $5 \mathrm{ml}$ of methanol. A solution of $\mathrm{NaOH}$ (185 $\mathrm{mg}, 4.61 \mathrm{mmol}$ ) in $20 \mathrm{ml}$ of methanol is added at once. The reaction mixture is now stirred for 12 hours at room temperature. Thereafter, $20 \mathrm{ml}$ of water is added to the reaction mixture and the organic solvent evaporated. The residue is acidified to $\mathrm{pH} 4$ with half-concentrated $\mathrm{HCl}$ and extracted with ethyl acetate. The combined organic layers are dried with $\mathrm{Na}_{2} \mathrm{SO}_{4}$. The solvent is removed in vacuo to give pure (5) (1.50 g, $3.84 \mathrm{mmol})$ as an off white solid in 99\% yield (based to the diester).

Analytical data: melting point $195^{\circ} \mathrm{C}, \mathrm{R}_{\mathrm{f}}$ 0.55(hexane/ethyl acetate/acetic acid) 1:1:0.1), ${ }^{1} \mathrm{H}$ NMR (500MHz, CD $\left.\mathrm{CD}_{3} \mathrm{OD}\right) \delta(\mathrm{ppm})=7.77(\mathrm{~d}, \mathrm{~J}=8.7 \mathrm{~Hz}, 1 \mathrm{H}, \mathrm{C}(3)-\mathrm{H}) ; 7.19(\mathrm{~d}, \mathrm{~J}=3.1 \mathrm{~Hz}, 1 \mathrm{H}$, $\mathrm{C}(6)-\mathrm{H}) ; 6.80\left(\mathrm{dd}, \mathrm{J}=8.7 \mathrm{~Hz}, \mathrm{~J}^{\prime}=3.1 \mathrm{~Hz}, 1 \mathrm{H}, \mathrm{C}(4)-\mathrm{H}\right) ; 4.39$ (s, 2H, $\mathrm{CH}_{2}$ methoxy); 1.60 (s, 9H, $t \mathrm{Bu}),{ }^{13} \mathrm{C}-\mathrm{NMR}\left(125.8 \mathrm{MHz}, \mathrm{CD}_{3} \mathrm{OD}\right): \delta(\mathrm{ppm})=175.7(\mathrm{COOH}) ; 168.0\left(\mathrm{COO}^{t} \mathrm{Bu}\right) ; 160.2(\mathrm{C}(5))$; 142.3 (C(3)); 140.1 (C(1)); 119.9 (C(4)); 117.8 (C(6)); 83.8 (quart C); 81.7 (C(2)); $68.4\left(\mathrm{CH}_{2}\right.$ methoxy); $28.3\left({ }^{t} \mathrm{Bu}\right)$, EI-MS $\left(210^{\circ} \mathrm{C}\right)$ calc. $\mathrm{m} / \mathrm{z} 378.0$, found $\mathrm{m} / \mathrm{z} 378.0$

Polymer-supported IBX (7). Compound 5 (1.28 g, $3.39 \mathrm{mmol})$ is dissolved in $5 \mathrm{ml}$ of DMF and 1-hydroxy-benzotriazol $(0.57 \mathrm{~g}, 3.73 \mathrm{mmol})$ is added. This mixture is added to a suspension of aminopropylsilica gel (3.00 g, $2.7 \mathrm{mmol}, \sim 0.8 \mathrm{mmol} \mathrm{g}^{-1}$ amino groups) in $30 \mathrm{ml}$ DMF. Thereafter diisopropylcarbodiimide $(0.52 \mathrm{ml}, 3.39 \mathrm{mmol})$ is added and the mixture is stirred over night. 
After 16 hours pyridine $(0.11 \mathrm{ml}, 1.35 \mathrm{mmol})$ and acetic anhydride $(0.13 \mathrm{ml}, 1.35 \mathrm{mmol})$ are added and the mixture is stirred again for 2 hours in order to block possible free amino groups. Now polymer 6 is filtered, thoroughly washed with DMF and methanol and dried in vacuo to constant weight. Yield 3.68g (92\%). Derivative 6 is suspended in a mixture of methylene chloride and trifluoroacetic acid $(9: 1,30 \mathrm{ml})$ and is agitated over night at room temperature. Thereafter the obtained compound is washed thoroughly with methanol and dried in vacuo to constant weight. A solution of oxone $(5.0 \mathrm{~g}, 8.1 \mathrm{mmol})$ in water $(50 \mathrm{ml})$ is added to the dry polymer. This suspension is stirred at $70{ }^{\circ} \mathrm{C}$ for 3 hours. After filtration and washing with water, the final reagent 7 is dried in vacuo. To determine the activity, $100 \mathrm{mg}$ of compound 7 are suspended in $0.5 \mathrm{ml}$ THF and benzylic alcohol is added $(6.0 \mathrm{mg}, 0.055 \mathrm{mmol})$. This suspension is agitated over night. The activity is determined by the ratio of educt to product and is normally in the range of 0.3-0.4 $\mathrm{mmol} \mathrm{g}^{-1}$.

Analytical data: IR (drift): $\widetilde{v}=3304,2941,1661$ (br), 1573, 1462, 1424, 1100, 950, $799 \mathrm{~cm}^{-1}$; $\mathrm{C} / \mathrm{H} / \mathrm{N}$ analysis: cal.: $\mathrm{N}=1.1, \mathrm{C}=10.8, \mathrm{H}=0.9$; found: $\mathrm{N}=0.8, \mathrm{C}=10.1, \mathrm{H}=1.8$.

Oxidations of alcohols. The alcohol is dissolved in THF ( $5 \mathrm{ml} / 1 \mathrm{~g}$ polymer), 1.2 eq. polymer 7 are added and the mixture is agitated over night at room temperature. Thereafter the reaction mixture is filtered and washed. The combined organic layers are dried over $\mathrm{Na}_{2} \mathrm{SO}_{4}$ and the solvent is removed in vacuo. If required, the products are purified by flash column chromatography.

Substrates 4a and 5a were kindly provided by P. Baumhof and R. Mazitschek. All other substrates and products in Table 1 are commercially available or known in literature. Analytical data of the products are consistent with the expected structures.

Analytical data of compound 4b. ${ }^{1} \mathrm{H}-\mathrm{NMR}\left(400 \mathrm{MHz}, \mathrm{CDCl}_{3}\right): \delta(\mathrm{ppm})=9.80(\mathrm{~d}, J=3.1 \mathrm{~Hz}, 1$ $\mathrm{H}, \mathrm{CHO}) ; 4.21$ (d, J=3.0 Hz, $1 \mathrm{H}, \mathrm{CH}) ; 3.98$ - 3.79 (m, $5 \mathrm{H}, 2$ x CH $2+\mathrm{CH}) ; 3.41\left(\mathrm{~s}, 3 \mathrm{H}, \mathrm{CH}_{3}\right)$; $3.04(\mathrm{dd}, J=11 \mathrm{~Hz}, J=3 \mathrm{~Hz}, 1 \mathrm{H}, \mathrm{CH}) ; 2.29(\mathrm{~d}, J=1.6 \mathrm{~Hz}, \mathrm{OH}) ; 1.97-1.85\left(\mathrm{~m}, 2 \mathrm{H}, \mathrm{CH}_{2}\right)$; 1.62-1.50 (m, $2 \mathrm{H}, \mathrm{CH}_{2}$ ); HR-MS (EI) cal.: 216.0997, found: 216.0983.

Analytical data of compound 5b. ${ }^{1} \mathrm{H}-\mathrm{NMR}\left(500 \mathrm{MHz}, \mathrm{CDCl}_{3}\right): \delta(\mathrm{ppm})=9.87(\mathrm{~d}, J=1.8 \mathrm{~Hz}, 1$ $\mathrm{H}, \mathrm{CHO}) ; 4.58(\mathrm{dd}, J=4.8 \mathrm{~Hz} ; J=8.7,1 \mathrm{H}, \mathrm{CH}) ; 4.28(\mathrm{~m}, 1 \mathrm{H}, \mathrm{CH}) ; 3.87-4.01$ (m, $4 \mathrm{H}$, $\left.\mathrm{OCH}_{2} \mathrm{CH}_{2} \mathrm{O}\right) ; 2.84(\mathrm{dd}, J=1.6 ; J=8.7,1 \mathrm{H}, \mathrm{CH}) ; 2.11(\mathrm{~m}, 1 \mathrm{H}, \mathrm{CH}) ; 1.92(\mathrm{ddt}, J=4.1, J=$ $13.4, J=15,1 \mathrm{H}, \mathrm{CH}) ; 1.81(\mathrm{dt}, J=4.4 ; J=13.3,1 \mathrm{H}, \mathrm{CH}) ; 1.58(\mathrm{ddd}, J=3.2, J=4.37, J=13.3$, $1 \mathrm{H}, \mathrm{CH}) ; 1.46\left(\mathrm{~s}, 3 \mathrm{H}, \mathrm{CH}_{3}\right) ; 1.34$ (s, 3H, $\left.\mathrm{CH}_{3}\right)$. HR-MS (EI): cal.: 242.1154, found.: 242.1159

\section{References}

1. Varvoglis, A. Hypervalent Iodine in Organic Synthesis; Academic Press: San Diego, California, 1997.

2. Varvoglis, A. Tetrahedron 1997, 53, 1179.

3. Varvoglis, A .; Spyroudis, S. Synlett 1998, 3, 221.

4. Stang, P. J.; Zhdankin, V. V. Chem. Rev. 1996, 96, 1123. 
5. Kirschning, A. Eur. J. Org. Chem. 1998, 2267.

6. Pohnert, G. J. prakt. Chem. 2000, 342, 731.

7. Frigerio, M.; Santagostino, M.; Sputore, S.; Palmisano, G. J. Org. Chem. 1995, 60, 7272.

8. Frigerio, M.; Santagostino, M.; Sputore, S. J. Org. Chem. 1996, 61, 9272.

9. Frigerio, M.; Santagostino, M. Tetrahedron Lett. 1995, 35, 8019.

10. Dess, D. B.; Martin, J. C. J. Org. Chem. 1983, 48, 4156.

11. Corey, E. J.; Palani, A. Tetrahedron Lett. 1995, 36, 7945.

12. Ley, S.; Schucht, O.;Thomas, A.; Murray, P. J.; J. Chem Soc., Perkin Trans 1 1999, 1251.

13. Clark, J.; Macquarrie, D. Chem. Commun. 1998, 853.

14. Ley, S.; Thomas, A.; Finch, H. J. Chem. Soc., Perkin Trans. 1 1999, 669.

15. Kirschning, A.; Monenschein, H.; Wittenberg, R. Angew. Chem. 2001, 113, 670; Angew. Chem., Int. Ed. 2001, 40, 650.

16. Ficht, S.; Mülbaier, M.; Giannis, A. Tetrahedron 2001, 57, 4863.

17. Widmer, U. Synthesis 1983, 135.

18. Frigerio, M.; Santagostino, M.; Sputore, S. J. Org. Chem. 1999, 64, 4537.

19. After four times usage of compound 7 no remarkable loss of activity has been noticed.

20. Nicolaou, K. C.; Baran, P. S.; Zhong, Y.; Vega, J. A. Angew. Chem. 2000, 112, 2625; Angew. Chem., Int. Ed. 2000, 39, 2525.

21. Nicolaou, K. C.; Zhong, Y.; Baran, P. S. Angew. Chem. 2000, 112, 636; Angew.Chem., Int. Ed. 2000, 39, 622.

22. Nicolaou, K. C.; Zhong, Y.; Baran, P. S. Angew. Chem. 2000, 112, 639; Angew. Chem., Int. Ed. 2000, 39, 625. 